\title{
Peningkatan Sekresi Angiotensinogen pada Kultur Sel Adiposit akibat Paparan Glukosa Suprafisologis secara Akut
}

\section{Increasing of Angiotensinogen Secretion in Adipocytes Culture Due to Acute Supraphysiological Glucose Exposure}

\author{
Novi Khila $F^{1}$, M Rasjad Indra ${ }^{2}$ \\ ${ }^{1}$ Laboratorium Biokimia-Biomolekuler Fakultas Kedokteran Universitas Brawijaya Malang \\ ${ }^{2}$ Laboratorium Fisiologi Fakultas Kedokteran Universitas Brawijaya Malang
}

\begin{abstract}
ABSTRAK
Salah satu mekanisme yang menerangkan patogenesis hipertensi pada obesitas adalah aktifasi sistem renin angiotensin. Angiotensinogen merupakan prekursor angiotensin II yang berperan dalam patofisiologi hipertensi. Ekspresi angiotensinogen dipengaruhi oleh kondisi lingkungan di sekitarnya. Penelitian sebelumnya secara in vivo memperlihatkan bahwa hiperglikemia dapat memodulasi ekspresi gen angiotensinogen di jaringan adiposa. Tujuan penelitian ini adalah ingin mengetahui apakah terjadi peningkatan sekresi angiotensinogen pada kultur sel adiposit yang di papar glukosa suprafisiologis selama 24 jam. Kultur sel adiposit diisolasi dari jaringan adiposa viseral tikus Rattus Novergicus strain Wistar jantan berusia 2-3 minggu. Kultur sel adiposit dibagi dalam 3 perlakuan, dipapar glukosa dengan konsentrasi 5 mM (sebagai kondisi fisiologis), $11 \mathrm{mM}$ dan $25 \mathrm{mM}$ sebagai kondisi glukosa tinggi, selama 24 jam. Dilakukan pengamatan kadar angiotensinogen pada medium kultur menggunakan ELISA. Hasil penelitian menunjukkan terdapat peningkatan yang signifikan kadar angiotensinogen pada medium kultur sel adiposit yang dipapar glukosa $25 \mathrm{mM}$ dibandingkan pada paparan glukosa $5 \mathrm{mM}(p=0,000)$ dan $11 \mathrm{mM}(p=0,002)$. Paparan glukosa tinggi $(25 \mathrm{mM})$ selama 24 jam dapat meningkatkan sekresi angiotensinogen pada kultur sel adiposit.
\end{abstract}

Kata Kunci: Angiotensinogen, glukosa suprafisiologis, kultur adiposit

\begin{abstract}
One mechanism that explains the pathogenesis hypertension in obesity is the activation of renin-angiotensin system. Angiotensinogen is precursor of angiotensin II, which plays an important role in pathophysiology of hypertension. Angiotensinogen expression level in adipocyte is influenced by the condition of their environment. Previous research showed that hyperglycemia can modulate angiotensinogen gene expression in adipose tissue. The purpose of this research was to know whether acute (24 hours) supraphysiologic glucose exposure can elevate angiotensinogen secretion in adipocyte culture. There were adipocytes cultures isolated from adipose viseral tissue of Rattus Novergicus rats (age 2-3 weeks), exposed with $5 \mathrm{mM}$ glucose (as physiological condition), $11 \mathrm{mM}$ and $25 \mathrm{mM}$ glucose for 24 hours. Detection of angiotensinogen concentrations in adipocyte culture medium was performed by ELISA. The results showed that angiotensinogen secretion in adipocyte culture exposed with $25 \mathrm{mM}$ is significantly higher than those of $5 \mathrm{mM}$ glucose $(p=0,000)$ and $11 \mathrm{mM}$ glucose $(p=0,002)$. It was concluded that the exposure of adipocyte with high glucose (25 $\mathrm{mM})$ in 24 hours increases the secretion of angiotensinogen.
\end{abstract}

Keywords: Adipocyte culture, angiotensinogen, supraphysiological glucose

Jurnal Kedokteran Brawijaya, Vol. 26, No. 3, Februari 2011; Korespondensi: Novi Khila F. Laboratorium Biokimia-Biomolekuler, Fakultas Kedokteran Universitas Brawijaya Malang, Jl. Veteran Malang Tel. (0341)569117Email: novikhila@yahoo.com 


\section{PENDAHULUAN}

Obesitas merupakan salah satu faktor risiko yang dapat meningkatkan kejadian hipertensi. Hasil penelitian memperlihatkan bahwa kenaikan berat badan sebesar 10 kilogram berasosiasi dengan kenaikan tekanan darah sistolik sebesar 3,0 $\mathrm{mm} \mathrm{Hg}$ dan tekanan darah diastolik sebesar 2,3 mmHg (1). Pada obesitas, distribusi jaringan lemak mempunyai implikasi yang penting dalam risiko timbulnya suatu penyakit. Berdasarkan hasil penelitian membuktikan ada hubungan antara obesitas abdominal dengan terjadinya penyakit kardiovaskuler seperti penyakit jantung koroner dan hipertensi (2-4). Namun mekanisme yang menerangkan hubungan obesitas abdominal dengan kejadian penyakit kardiovaskuler masih belum jelas. Ada dugaan bahwa sel adiposit intraabdominal lebih aktif dalam mensekresi berbagai molekul yang berperan dalam metabolisme dibandingkan sel adiposit di bagian lain dalam tubuh (4).

Salah satu mekanisme yang menerangkan terjadinya hipertensi pada obesitas adalah melalui aktifasi sistem renin angiotensin (RAS). Penelitian pada tikus yang diberi diet tinggi lemak untuk menginduksi terjadinya obesitas memperlihatkan adanya peningkatan tekanan darah yang disebabkan oleh peningkatan aktifasi RAS (5). Penelitian lain pada tikus transgenik yang meng-over ekspresikan angiotensinogen hanya di jaringan lemak menunjukkan peningkatan angiotensinogen plasma dan terjadi peningkatan tekanan darah (6). Hal ini menunjukkan adanya peran angiotensinogen dari jaringan lemak dalam regulasi tekanan darah.

Sel adiposit diketahui dapat memproduksi angiotensinogen serta beberapa komponen lainnya yang berperan dalam RAS, selain hepar sebagai organ primer penghasil angiotensinogen (7). Dalam RAS, angiotensinogen merupakan prekursor untuk membentuk angiotensin II, yang mana angiotensin II merupakan efektor utama yang memediasi terjadinya hipertensi (8). Hiperglikemia diketahui merupakan salah satu faktor yang dapat memodulasi ekspresi gen angiotensinogen di jaringan adiposa (9). Penelitian ini ingin mengetahui apakah pada kultur sel adiposit yang di papar glukosa tinggi secara akut (24 jam) juga dapat meningkatkan sekresi angiotensinogen.

\section{METODE}

\section{Objek Penelitian}

Sebagai objek penelitian ini adalah kultur sel adiposit yang diisolasi dari jaringan adiposa viseral tikus Rattus Novergicus strain Wistar jantan berusia 2-3 minggu. Kultur sel adiposit diberi paparan glukosa dengan konsentrasi $5 \mathrm{mM}$ (sebagai kondisi fisiologis), serta glukosa $11 \mathrm{mM}$ dan $25 \mathrm{mM}$ sebagai kondisi glukosa suprafisiologis selama 24 jam (10).

\section{Isolasi dan Pembuatan Kultur Sel Adiposit}

Pembuatan kultur sel adiposit diperoleh dari hasil isolasi preadiposit dari jaringan adiposa viseral tikus jantan Rattus Novergicus usia 2-3 minggu. Terlebih dahulu jaringan fibrous dan pembuluh darah dibuang, kemudian jaringan adiposa dicuci dengan $10 \mathrm{~mL}$ larutan PBS, selanjutnya dicacah. Suspensi jaringan tersebut diinkubasi dengan $0,2 \% \mathrm{mg} / \mathrm{ml}$ Collagenase tipe I (Sigma) selama 45 menit, suhu $37^{\circ} \mathrm{C}$ dengan shaking. Inkubasi dihentikan dengan menambahkan media kultur (DMEM/F12 (1:1) yang ditambahkan dengan $15 \mathrm{mmol} / \mathrm{I} \mathrm{HEPES}, 14 \mathrm{mmol} / \mathrm{l}$ $\mathrm{NaHCO}_{3}, 33 \mu \mathrm{mol} / \mathrm{I}$ biotin, $17 \mu \mathrm{mol} / \mathrm{I}$ D-pantothenate dan $10 \%$ FBS. Suspensi sel diputar 1500 rpm selama 7 menit, sehingga didapatkan pelet yang mengandung fibroblastlike preadipocyte. Selanjutnya pelet diresuspensi dengan media kultur kemudian sel diputar 1500 rpm selama 7 menit. Pelet diresuspensi lagi dengan media kultur. Suspensi sel ditumbuhkan pada culture plate dengan inkubasi pada suhu $37^{\circ} \mathrm{C}, 5 \% \mathrm{CO}_{2}$ selama 24 jam. Sel dicuci setiap 3 hari sekali. Setelah mencapai monolayer, preadiposit ditumbuhkan dalam media adipogenik (DMEM/F12 dengan ditambahkan $100 \mathrm{U} / \mathrm{ml}$ Penisilin dan $100 \mathrm{U} / \mathrm{ml}$ Streptomisin, serta $66 \mathrm{nM}$ insulin, $100 \mathrm{nM}$ dexamethasone, 0,5 mM IBMX dan $10 \mu \mathrm{g} / \mathrm{ml}$ transferin) untuk stimulasi diferensiasi sel preadiposit menjadi sel adiposit matur (11).

\section{Paparan Glukosa}

Setelah kultur sel preadiposit diinduksi differensiasi selama 24 jam menjadi sel adiposit yang matur (11), kemudian pada medium kultur dipaparkan glukosa dengan 3 konsentrasi yang berbeda, yakni konsentrasi $5 \mathrm{mM}$ sebagai kondisi fisiologis, serta konsentrasi glukosa $11 \mathrm{mM}$ dan 25 mM sebagai kondisi suprafisiologis. Sel diinkubasi selama 24 jam sebelum dilakukan pengukuran variabel penelitian.

Pemeriksaan Morfologi Sel Adiposit dengan Pengecatan Oil Red O

Untuk mengamati morfologi sel adiposit dilakukan metode pengecatan dengan oil red $O$. Sel pada masing-masing perlakuan difiksasi dengan $10 \%$ formalin. Sel dicuci dengan aquades kemudian dikeringkan. Selanjutnya ditetesi dengan propylene glycol 2 kali selama masing-masing 5 menit. Setelah itu sel ditetesi dengan Oil Red O selama 7 menit kemudian diagitasi. Sel dicuci dengan aquades kemudian ditetesi hematoxylin selama 1 menit. Kemudian sel dicuci lagi dengan aquades dan ditunggu sampai kering, setelah itu diamati dengan mikroskop cahaya merk Olympus pada perbesaran $400 \times(12)$.

\section{Pengukuran Kadar Angiotensinogen dengan ELISA}

Antigen (kadar antigen $1 \mathrm{~g} / \mathrm{ml}$ ) dalam coating buffer (1:9) didapatkan dengan melarutkan dalam TBS sampai $1 \mathrm{ml}$ hingga memiliki kadar $10 \mathrm{~g} / \mathrm{ml}$ dan ditambahkan coating buffer hingga $10 \mathrm{ml}$. Antigen di-coating pada plate ELISA selama semalam pada suhu 4C, dicuci dalam PBS-Tween $3 \times 3$ menit, diblok dengan blocking buffer (BSA 1\% dalam PBS) 50 I / well, diinkubasi selama 2 jam suhu ruang, dicuci dalam PBS-Tween $3 \times 3$ menit. Coating antibodi primer (50 I /well) dengan inkubasi selama 2 jam pada suhu ruang. Dicuci dalam PBS-Tween $3 \times 3$ menit. Coating antibodi sekunder Anti Rabbit IgG AP Conjugated (1:2500) dalam TBS melalui inkubasi selama 2 jam pada suhu ruang, dicuci dalam PBS-Tween $3 \times 3$ menit, ditambahkan substrat pNPP dalam dietanolamin 10\% (50 I / well), diinkubasi 30 menit, suhu ruang, kemudian ditambahkan $\mathrm{NaOH} 3 \mathrm{M}$ (50 l/ well) sebagai stop reaction. Setelah 15 menit, dibaca dengan ELISA reader pada $\lambda=405 \mathrm{~nm}$ (13).

\section{Analisa Data}

Data hasil pengukuran kadar angiotensinogen pada 
masing-masing perlakuan ditampilkan dalam mean \pm SD. Analisa data menggunakan One Way ANOVA pada tingkat kepercayaan $\alpha=0,05$, dilanjutkan uji Tukey untuk melihat perbedaan masing-masing variabel. Dilakukan uji regresi korelasi untuk mengetahui pengaruh paparan glukosa dalam 3 kelompok perlakuan terhadap kadar angiotensinogen yang disekresikan pada medium kultur sel adiposit. Analisa data dilakukan dengan SPSS versi 14.

\section{HASIL}

\section{Morfologi Kultur Sel Adiposit}

Pemeriksaan morfologi kultur sel adiposit dilakukan dengan menggunakan pengecatan Oil Red $O$ untuk mendeteksi adanya droplet lipid, karena secara fisiologis sel lemak berperan sebagai tempat menyimpan cadangan enersi berupa triasil gliserol yang nampak sebagai droplet lipid. Droplet lipid pada sel adiposit dengan pengecatan Oil Red O tampak berwarna merah. Sebagai counterstain digunakan hematoxylen untuk mewarnai bagian sel lainnya yang nampak berwarna biru (12). Hasilnya digambarkan pada Gambar 1.

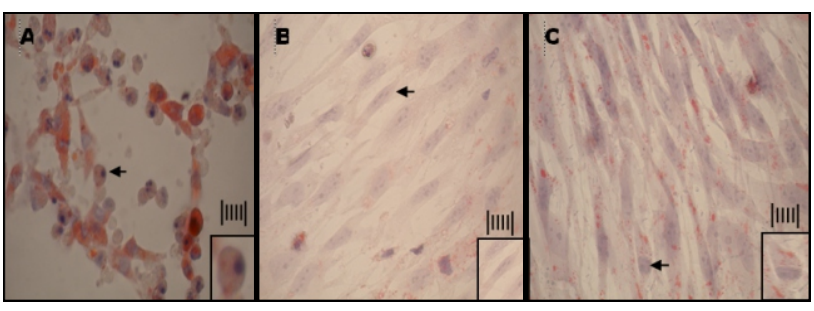

Gambar 1. Morfologi kultur sel adiposit dengan pengecatan oil red $O$ yang diamati dengan mikroskop cahaya (pembesaran 400x)

Keterangan :

A. Kultur adiposit yang dipapar glukosa $5 \mathrm{mM}$

B. Kultur adiposit yang dipapar glukosa $11 \mathrm{mM}$

C. Kultur adiposit yang dipapar glukosa $25 \mathrm{mM}$

Pada Gambar 1 tampak bahwa pada kultur sel adiposit yang dipapar glukosa $5 \mathrm{mM}$ (Gambar 1A) menunjukkan gambaran sel adiposit yang normal (ditunjukkan dengan tanda panah), yang mempunyai ciri-ciri bentuk sel bulat dengan inti sel yang jelas di bagian perifer sel, membran sel yang rata disertai adanya droplet lipid yang besar hampir memenuhi bagian sel. Pada kultur sel adiposit yang dipapar glukosa $11 \mathrm{mM}$ dan $25 \mathrm{mM}$ menunjukkan gambaran sel adiposit yang mengalami nekrosis (ditunjukkan dengan tanda panah) yang digambarkan pada gambar 1B dan 1C. Hal ini ditandai dengan sel adiposit yang mengalami pembesaran atau menggelembung (blebbing), inti sel terpecah menjadi banyak gumpalan atau karioreksis (Gambar 1B) dan inti sel nampak pucat atau kariolisis (Gambar 1C). Tampak lebih sedikit droplet lipid pada sel adiposit yang dipapar glukosa $11 \mathrm{mM}$ dan $25 \mathrm{mM}$ dibandingkan pada kultur sel adiposit yang dipapar glukosa $5 \mathrm{mM}$.

\section{Hasil Pengukuran Kadar Angiotensinogen dengan ELISA}

Hasil pengukuran rata-rata kadar angioten-sinogen yang disekresikan pada medium kultur sel adiposit yang dipapar glukosa $5 \mathrm{mM}, 11 \mathrm{mM}$ dan $25 \mathrm{mM}$ dengan menggunakan metode ELISA digambarkan pada Gambar 2.

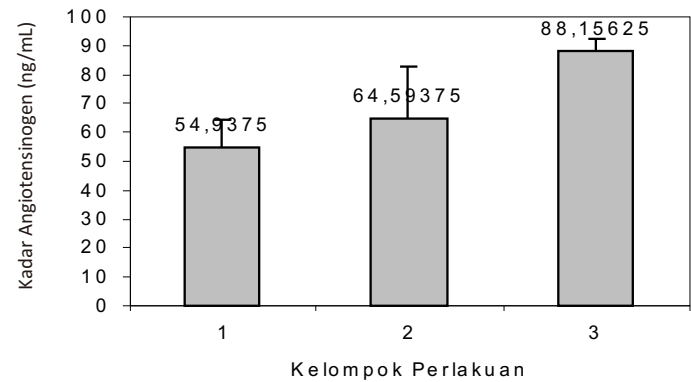

Gambar 2. Diagram rerata kadar angiotensinogen berdasarkan kelompok perlakuan (dalam $\mathrm{ng} / \mathrm{mL}$ )

Keterangan :

A. Kultur adiposit yang dipapar glukosa $5 \mathrm{mM}$

B. Kultur adiposit yang dipapar glukosa $11 \mathrm{mM}$

C. Kultur adiposit yang dipapar glukosa $25 \mathrm{mM}$

Dari diagram pada Gambar 2 tampak bahwa rata-rata kadar angiotensinogen paling banyak disekresikan oleh kultur sel adiposit yang dipapar dengan glukosa $25 \mathrm{mM}$. Berdasarkan uji statistik menggunakan analisis One Way ANOVA $(\alpha=0,05)$ didapatkan adanya perbedaan yang nyata kadar angiotensinogen pada paparan glukosa $25 \mathrm{mM}$ dibandingkan kadar angiotensinogen pada paparan glukosa $5 \mathrm{mM}(\mathrm{p}=0,000)$ dan pada paparan glukosa $11 \mathrm{mM}$ $(p=0,002)$. Kadar angiotensinogen tertinggi terjadi pada paparan glukosa $25 \mathrm{mM}$, sedangkan kadar angiotensinogen pada paparan glukosa $11 \mathrm{mM}$ tidak berbeda nyata dengan kadar angiotensinogen pada paparan glukosa $5 \mathrm{mM}(p=0,263)$. Hasil uji korelasi diketahui ada pengaruh yang signifikan paparan glukosa terhadap kadar angiotensinogen $(r=0,758 ; p=0,000)$.

\section{DISKUSI}

Paparan glukosa suprafisiologis dapat memberikan pengaruh yang signifikan terhadap perubahan morfologi maupun kelainan fungsi pada kultur sel adiposit sebagai salah satu sel yang dapat mensekresikan angiotensinogen. Glukosa dapat masuk ke dalam sel adiposit melalui difusi fasilitatif yang diperantarai oleh glukosa transporter (GLUT). Ada beberapa isoform GLUT yang diketahui terdistribusi di beberapa jaringan, yakni GLUT1 sampai dengan GLUT6. Di sel adiposit, transportasi glukosa melibatkan GLUT1 dan GLUT4. GLUT1 merepresentasikan glukosa transporter yang predominan di jaringan yang tidak bergantung insulin, seperti otak dan eritrosit, namun didapatkan juga di sel otot skelet dan adiposit. Isoform GLUT4 merupakan glukosa transporter yang bergantung pada insulin yang predominan di sel otot skelet dan adiposit $(14,15)$.

Dari hasil pengamatan morfologi sel adiposit menggunakan pengecatan Oil Red O (Gambar 1) tampak bahwa pada kultur sel adiposit yang diberi paparan glukosa $5 \mathrm{mM}$ sebagai kondisi fisiologis memiliki karakteristik morfologi sel adiposit yang normal, yakni bentuk sel bulat dengan inti sel yang jelas di bagian perifer sel, membran sel yang halus dan nampak adanya droplet lipid yang besar hampir memenuhi bagian sel (Gambar 1A). Gambaran ini sesuai dengan karakteristik sel adiposit matur menurut Junqueira (16) yang menyatakan bahwa sel adiposit matur dari jaringan lemak putih memiliki bentuk sel bulat dengan droplet lipid yang sangat besar, sehingga menempatkan 
inti sel (nukleus) dan sitoplasma pada bagian perifer sel. Pada kultur sel adiposit yang dipapar glukosa $11 \mathrm{mM}$ dan $25 \mathrm{mM}$ terjadi perubahan morfologi sel adiposit yang abnormal, ditandai dengan sel adiposit yang mengalami pembesaran (membran blebbing) dan membran sel yang tidak rata. Inti sel tampak mengalami karioreksis (Gambar $1 B)$, yakni inti yang terpecah menjadi banyak gumpalan serta mengalami kariolisis, yakni inti sel pucat (Gambar 1C). Tampak sedikit lipid droplet pada sel adiposit yang menunjukkan adanya disfungsi sel adiposit sebagai penyimpan cadangan lemak berupa triasil gliserol. Pada hasil pengamatan morfologi sel adiposit yang dipapar glukosa $11 \mathrm{mM}$ dan $25 \mathrm{mM}$ dapat disimpulkan bahwa terjadi nekrosis pada sel adiposit. Menurut Robbins (17), terdapat dua bentuk kematian sel yang masing-masing mempunyai ciri-ciri morfologi yang berbeda, yaitu apoptosis dan nekrosis. Pada apoptosis terjadi kematian sel yang terprogram, yakni fragmentasi kromatin, inti sel menjadi padat, ukuran sel mengecil dan badan sel mengkerut. Sedangkan pada nekrosis, sel nampak menggelembung (swelling), kromatin menggumpal, hilangnya integritas organel sel dan membran plasma, yang pada akhirnya sel menjadi pecah (membran damage). Perubahan morfologis dasar pada apoptosis dan nekrosis disebabkan terjadinya denaturasi protein dan pencernaan enzimatik organel dan sitosol. Patomekanisme terjadinya kematian sel disebabkan oleh jejas pada sel, salah satunya akibat senyawa oksigen reaktif (ROS) di dalam sel yang berasal dari reaksi oksidatif metabolik yang berlebihan. ROS yang dihasilkan pada paparan glukosa tinggi dapat mengaktifkan ASK1 (apoptosis signal-regulating kinase) yang merupakan sensor adanya stress oksidatif.

Penyebab utama terjadinya stress oksidatif sel pada kondisi hiperglikemia dikarenakan meningkatnya pembentukan mitochondrial ROS, selain itu juga disebabkan oleh aktifitas enzim NADPH oksidase yang berperan dalam pembentukan radikal superoksida (18). Mitokondria merupakan organel sel yang berperan dalam reaksi fosforilasi oksidatif dalam kaitannya dengan oksidasi glukosa menjadi ATP, sumber energi bagi sel. Terjadinya peningkatan mitochondrial ROS pada kondisi hiperglikemia disebabkan meningkatnya oksidasi glukosa pada siklus asam sitrat, yang menyebabkan peningkatan donor elektron yang mendorong rantai transpor elektron di mitokondria. Akibatnya terjadi peningkatan gradien voltase di membran mitokondria hingga mencapai titik critical treshold. Pada titik ini transfer elektron di dalam kompleks III menjadi terhambat, menyebabkan elektron kembali ke koenzim $Q$, dan mendonorkan elektron pada molekul oksigen sehingga menghasilkan radikal superoksid (19).

Selain menimbulkan kelainan struktur sel adiposit, paparan glukosa tinggi juga dapat menyebabkan kelainan fungsi atau disfungsi sel, akibat terjadinya ketidakseimbangan jalur biokimia intraseluler. Efek paparan glukosa tinggi dilaporkan dapat mengaktifkan beberapa jalur reaksi biokimia, yaitu jalur polyol, jalur heksosamin, jalur protein kinase C dan jalur AGE (advance glicosylation end products), yang berakibat pada teraktifasinya stress-sensitive signaling pathways $(18,19)$. Terjadinya disfungsi sel pada kultur sel adiposit yang dipapar glukosa $11 \mathrm{mM}$ dan $25 \mathrm{mM}$ salah satunya ditandai dengan menurunnya kemampuan menyimpan cadangan energi dalam bentuk triasil gliserol, yang terlihat pada berkurangnya droplet lipid intrasel. Selain itu, disfungsi sel adiposit juga nampak dalam regulasi sekresi protein, dalam hal ini yang diamati adalah sekresi angiotensinogen.

Pada penelitian ini diperoleh hasil bahwa pada paparan glukosa $25 \mathrm{mM}$ terjadi peningkatan sekresi angiotensinogen yang signifikan dibandingkan dengan sekresi angiotensinogen pada kultur sel adiposit yang dipapar glukosa $5 \mathrm{mM}$ dan $11 \mathrm{mM}$. Akan tetapi pada kultur sel adiposit yang dipapar glukosa $11 \mathrm{mM}$, tidak terjadi peningkatan kadar angiotensinogen yang bermakna dibandingkan pada paparan glukosa normal (5 mM). Hasil uji korelasi menunjukkan bahwa glukosa berpengaruh secara signifikan terhadap peningkatan kadar angiotensinogen. Peningkatan sekresi angiotensinogen pada kultur sel adiposit yang dipapar glukosa $25 \mathrm{mM}$ diduga disebabkan oleh adanya peningkatan ROS. Hal ini berdasarkan penelitian sebelumnya secara in vitro pada sel tubular ginjal yang dipapar glukosa $25 \mathrm{mM}$, terjadi peningkatan ekspresi mRNA angiotensinogen yang disebabkan oleh peningkatan pembentukan ROS (20).

Angiotensinogen merupakan protein yang termasuk dalam acute phase protein, yang mana ekspresinya diregulasi oleh berbagai faktor. Penelitian Frederich (21) pada hewan coba didapatkan hasil bahwa regulasi ekspresi gen angiotensinogen di sel adiposit dilaporkan dipengaruhi oleh faktor nutrisi, yakni dapat menginduksi upregulation gen angiotensinogen. Penelitian lebih lanjut oleh Gabriely (9) pada tikus yang diberi paparan glukosa tinggi sampai dengan $18 \mathrm{mM}$ dapat menyebabkan peningkatan ekspresi gen angiotensinogen di jaringan adiposa.

Pada paparan glukosa $11 \mathrm{mM}$, kadar angiotensinogen tidak berbeda dengan kultur sel adiposit yang dipapar glukosa $5 \mathrm{mM}(\mathrm{p}=0,263)$. Dapat disimpulkan bahwa pada paparan glukosa $11 \mathrm{mM}$ belum memberikan efek terhadap peningkatan kadar angiotensinogen di sel adiposit. Diduga bahwa pada kadar glukosa 11 mM yang dipaparkan selama 24 jam pada kultur sel adiposit, pembentukan ROS masih belum optimal sehingga belum menimbulkan pengaruh yang signifikan terhadap peningkatan kadar angiotensinogen, karena pada proses pembentukan ROS di dalam sel terdapat fluktuasi yang dipengaruhi oleh lama paparan glukosa tinggi. Hal ini didasarkan penelitian Ying dan $\mathrm{Wu}$, yang menunjukkan bahwa pada paparan glukosa tinggi ( $25 \mathrm{mM}$ ) terjadi peningkatan produksi $\mathrm{H}_{2} \mathrm{O}_{2}$ tiga kali lebih banyak pada lama paparan 4 jam dan 2 kali lebih banyak pada lama paparan 8 hari dibandingkan kultur sel adiposit yang dipapar glukosa $5 \mathrm{mM}(10,22)$.

Mekanisme peningkatan kadar angiotensinogen di sel adiposit pada paparan glukosa tinggi $(25 \mathrm{mM})$ diduga melalui beberapa jalur biokimia akibat peningkatan ROS, yang menyebabkan penurunan aktifitas enzim glyceraldehyde-3 phosphate dehydrogenase (GAPDH) yang mengkatalisa reaksi pembentukan 1,3 diphospholiserat dari gliseraldehida-3-phosphat. Ada empat jalur reaksi biokimia yang diaktifkan pada kondisi hiperglikemia, yaitu jalur polyol, jalur heksosamin, jalur protein kinase C dan jalur AGE (advance glicosylation end products) (19). Aktifasi jalur polyol akan menyebabkan peningkatan produksi sorbitol yang bersifat toksik, yang selanjutnya dapat mengaktifkan enzim p38 MAPK (24). Penelitian pada sel tubular ginjal melaporkan bahwa enzim p38 MAPK dapat mengaktifkan faktor transkripsi yang berperan pada ekspresi gen angiotensinogen (20). 
Akibat kondisi hiperglikemia pada sel juga akan mengaktifkan jalur heksosamin. Jalur heksosamin dilaporkan dapat meningkatkan ekspresi angiotensinogen di jaringan adiposa (9). Jalur penting lainnya yang diaktifkan pada kondisi hiperglikemia yaitu aktifasi enzim protein kinase C (PKC). Enzim PKC adalah enzim yang memfosforilasi substrat protein pada residu serin atau threonin. Penelitian pada kultur sel adiposit yang dipapar glukosa tinggi diperoleh hasil bahwa paparan glukosa tinggi dapat mengaktifkan enzim PKC-d. Aktifasi PKC dapat menimbulkan berbagai efek pada ekpresi beberapa gen intrasel (23).

Di sel adiposit, angiotensinogen sebagai prekursor angiotensin II sebenarnya mempunyai peran yang sangat penting, yakni berfungsi untuk meningkatkan pertumbuhan dan maturasi sel adiposit (24). Hasil penelitian juga menunjukkan adanya perbedaan ekspresi mRNA angiotensinogen dan protein angiotensinogen antara tikus muda (usia 8 minggu) dan dewasa (usia 26 minggu), yang mana pada tikus muda 3 kali lebih banyak dibandingkan tikus dewasa (25). Sehingga dapat ditarik benang merah dari hasil penelitian ini, bahwa fenomena terjadinya peningkatan sekresi angiotensinogen pada sel adiposit yang dipapar glukosa $25 \mathrm{mM}$ yang menunjukkan gambaran

\section{DAFTAR PUSTAKA}

1. Brown $C D$, Higgins $M$, Donato KA, et al. Body Mass Index and the Prevalence of Hypertension and Dyslipidemia. Obesity Research. 2000; 8(9): 605619.

2. Grundy SM. Metabolic Syndrome: Connecting and Reconciling Cardiovascular and Diabetes Worlds. American College of Cardiology Fundation. 2006; 47(6): 1093-100.

3. Sironi AM, Gastaldelli A, Mari A, et al. Visceral Fat in Hypertension Influence on Insulin Resistance and $\beta$ Cell Function. Hypertension. 2004; 44(2): 127-133.

4. Flier JS. Obesity. In: Braunwald E (Ed). Harrison's Principles of Internal Medicine 15th edition. New York: Mc Graw Hill; 2001.

5. Dobrian AD, Davies MJ, and Prewitt RL. Development of a Rat Model of Diet-Induced Obesity. Hypertension. 2000; 35(4): 1009-1015.

6. Engeli S, Negrel R, and Sharma AM. Physiology and Pathophysiology of the Adipose Tissue ReninAngiotensin System. Hypertension. 2000;35: 12701277.

7. Kershaw EE and Flier JS. Adipose Tissue as an Endocrine Organ. The Journal of Clinical Endocrinology and Metabolism. 2004; 89(6): 2548-2556.

8. Vikrant S and Tiwari SC. Essential Hypertension-Pathogenesis and Pathophysiology. Journal Indian Academy of Clinical Medicine. 2001; 2(3): 140-162.

9. Gabriely I, Yang XM, Cases JA, Ma XH, Rosseti L, and Barzilai N. Hyperglycemia Modulates Angiotensinogen Gene Expression. American Journal morfologis sel adiposit yang mengalami nekrosis, diduga merupakan mekanisme untuk mempertahankan hidup sel adiposit dalam rangka menghindari kematian sel. Namun dampak yang merugikan secara sistemik adalah bisa meningkatkan kadar angiotensinogen dalam plasma yang bisa menyebabkan peningkatan tekanan darah.

Berdasarkan hasil penelitian ini dapat disimpulkan bahwa paparan akut glukosa suprafisiologis ( $25 \mathrm{mM}$ ) selama 24 jam dapat meningkatkan sekresi angiotensinogen oleh sel adiposit. Peningkatan sekresi angiotensinogen pada kultur sel adiposit tersebut diduga akibat peningkatan produksi ROS.

Perlu dilakukan penelitian lanjutan menggunakan waktu paparan lebih dari 24 jam untuk mengetahui efek paparan glukosa tinggi terhadap fluktuasi sekresi angiotensinogen pada kultur sel adiposit.

\section{UCAPAN TERIMA KASIH}

Penulis menyampaikan ucapan terima kasih kepada Dekan FKUB dan Prof. dr. M. Aris Widodo, PhD., SpFK. selaku ketua Unit Pengembangan Penelitian FKUB, atas didanainya penelitian ini, dan kepada Prof. Dr. drh. Aulanniam, DESS. atas diskusi dan saran-sarannya.

of Physiology Regulatory, Integrative and Comparative Physiology. 2001;281(2): R795-R802.

10. Wu X, Zhu L, Zilbering A, et al. Goldstein. Hyperglycemia Potentiates $\mathrm{H}_{2} \mathrm{O}_{2}$ Production in Adipocytes and Enhances Insulin Signal Transduction: Potential Role for Oxidative Inhibition of ThiolSensitive Protein-Tyrosine Phosphatases. Antioxidant and Redox Signaling. 2005;7(5-6): 526-537.

11. Indra MR, Satuman, and Widodo E. Optimalisasi Proliferasi dan Diferensiasi Sel Adiposit Tikus. [Report]. Universitas Brawijaya, Malang. 2005.

12. Gregoire F, Smas CM, and Sul HS. Understanding Adipocyte Differentiation. Physiological Reviews. 1998; 78(3): 783-809.

13. Aubert J, Safnova I, Negre R, and Ailhaud G. Insulin Down-Regulates Angiotensinogen Gene Expression and Angiotensinogen Secretion in Cultured Adipose Cells. Biochemical Biophysical Research Communication. 1998; 250(1): 77-82.

14. DeFronzo RA. Pathogenesis of Type 2 Diabetes Mellitus: Metabolic and Molecular Implications for Identifying Diabetes Genes. Diabetes. 1997; 5: 117269.

15. Fujisiro $M$, Gotoh $\mathrm{Y}$, Katagiri $\mathrm{H}$, et al. $M K K 6 / 3$ and $p 38$ MAPK Pathway Activation is Not Necessary for Insulininduced Glucose Uptake but Regulates Glucose Transporter Expression. The Journal of Biological Chemistry. 2001; 276(23): 19800-19806.

16. Junqueria LC and Carneiro J. Basic Histology: Text \& Atlas. 11th edition. Singapore: McGraw-Hill, 2005.

17. Robbins SL, Cotran RS and V. Kumar. Pocket Companion to Pathologic Basis of Disease. Philadelphia: WB Saunders Company; 1996. 
18. Evans JL, Goldfine ID, Maddux BA, and Grodsky GM. Oxidative Stress and Stress-Activated Signaling Pathways: A Unifying Hypothesis of Type 2 Diabetes. Endocrine Reviews. 2002; 23(5): 599-622.

19. Brownlee M. The Pathobiology of Diabetic Complications a Unifying Mechanism. Diabetes. 2005; 54(6): 1615-1625.

20. Hsieh TJ, Zhang SL, Filep JG, Tang SS, Ingelfinger JR, and Chan S. High Glucose Stimulates Angiotensinogen Gene Expression via Reactive Oxygen Species Generation in Rat Kidney Proximal Tubular Cells. Endocrinology. 2002; 143(8): 2975-2985.

21. Frederich RCJr, Kahn BB, Peach MJ, and Flier JS. Tissue-Specific Nutritional Regulation of Angiotensinogen in Adipose Tissue. Hypertension. 1992; 19(4): 339-344.
22. Lin $\mathrm{Y}$, Berg $\mathrm{AH}$, lyngar $\mathrm{P}$, et al. The Hyperglycemiainduced Inflammatory Response in Adipocytes. The Role of Reactive Oxygen Species. The Journal of Biological Chemistry. 2005; 280(6): 46174626.

23. Talior I, Tennenbaum T, Kuroki T, and Eldar-Finkelman H. PKC- $\delta$-Dependent Activation of Oxidative Stress in Adipocytes of Obese and Insulin-Resistant Mice: Role for NADPH Oxidase. American Journal of Physiology Endocrinology and Metabolism. 2005;288(2): E405E411.

24. Massiera F, Bloch-Faure M, Ceiler D, et al. Adipose Angiotensinogen is Involved in Adipose Tissue Growth and Blood Pressure Regulation. The Journal of the Federation of American Societies for Experimental Biology. 2001;15: 2727-2729.

25. Paul M, Poyan Mehr A, and Kreutz R. Physiology of Local Renin-Angiotensin Systems. Physiological Review. 2006; 86: 747-803. 